\title{
Uptake of foreign ferritin in platy Xiphophorus maculatus (Poeciliidae: Teleostei)
}

\author{
Ingvar Leiv Leknes* \\ Faculty of Science, Sogn og Fjordane University College, Box 133, 6851 Sogndal, Norway
}

\begin{abstract}
The ability and capacity of various tissues in platy Xiphophorus maculatus L. to take up horse-spleen ferritin injected into the blood stream are described. Ferritin was injected intraperioneally, and the cellular uptake was demonstrated as Prussian blue precipitations in tissues treated with acid ferrocyanide solutions. Ferritin was detected within the heart endocardial cells and macrophages in the trunk kidney and spleen, $1 / 4 \mathrm{~h}$ after the injection, i.e. foreign ferritin was taken up very rapidly by these cells. When the time elapsed between the ferritin injection and sacrifice exceeded $6 h$, these cells, and also macrophages in the gill and intestine, were almost completely filled with ferritin. At these stages, however, the amounts of Prussian blue precipitations per volume unit of the tissue were much larger in the heart than in the other organs studied in the present work, i.e. the endocardial tissue seems to play an important role in the clearance of the blood circulation in this species. We suggest that this tissue in platy is specialized to endocytose waste and foreign macromolecules, including pathogenic particles, from the blood stream. The eosinophilic and neutrophilic granulocytes do not appear to take up foreign ferritin, i.e. these cells may play no endocytotic role in the clearance of foreign macromolecules in platy.
\end{abstract}

KEY WORDS: Endocytose $\cdot$ Endocardium $\cdot$ Sinusoidal endothelium $\cdot$ Macrophages $\cdot$ Ferritin $\cdot$ Platy

Resale or republication not permitted without written consent of the publisher

Previously, it has been shown that the heart endocardial cells in platy Xiphophorus maculatus L. are able to endocytose and store large amounts of horsespleen ferritin from injection into the blood stream during a $24 \mathrm{~h}$ period (Leknes 1987, 2001a). The main purpose of the present work was to examine and compare the ability and capacity of the heart, trunk kidney, spleen, intestine, gills and skin tissues to take up horse spleen ferritin from the circulation in platy. We also intended to reveal the ability of the eosinophilic gran-

*E-mail: ingvar.leknes@hisf.no ulocytes and neutrophilic granulocytes in this species to internalize foreign ferritin.

Material and methods. Thirty-five specimens of platy Xiphophorus maculatus L., 1 to $3 \mathrm{yr}$ old, mass $0.5 \mathrm{~g}$, kept in a well-aerated aquarium at $21^{\circ} \mathrm{C}$, were injected intraperitoneally with 0.03 to $0.05 \mathrm{ml} 10 \%$ solutions of horse-spleen ferritin (Sigma) by means of $0.5 \mathrm{ml}$ tuberculin syringes (Becton Dickingson). After $1 / 4,1 / 2,1,1.5$, $2,3,4,5,6,7,11,21,24$, and $28 \mathrm{~h}$, fish were killed with an overdose of chlorobutanol, and the heart, trunk kidney, spleen, intestine, gills and skin were quickly excised and fixed at $4{ }^{\circ} \mathrm{C}$ in $4 \%$ formaldehyde, made up from paraformaldehyde $24 \mathrm{~h}$ before use, in phosphate buffer. The same tissues from 5 uninjected specimens, were also fixed as control specimens. After washing in buffer, the tissues were dehydrated through an ethanol series, treated with xylene, embedded in paraffin wax and sectioned. Dewaxed sections were treated with a ferrocyanide solution, made by dissolving $2 \mathrm{~g}$ potassium ferrocyanide in $100 \mathrm{ml} 0.75 \mathrm{M}$ hydrochloric acid solution in order to visualize ferritin-iron ions (Pearse 1980). Then, the sections were treated with a $1 \%$ aquatic solution of neutral red and/or $1 \%$ aquatic solution of eosin (Grimstone \& Skaer 1972).

We used platy in this study because it is much easier and cheaper to work with this species than with small specimens of cod or salmon.

Results. Tissues from ferritin injected platy specimens: A few heart endocardial cells displayed Prussian blue precipitations, diameter 1 to $2 \mu \mathrm{m}, 1 / 4 \mathrm{~h}$ after the ferritin injection, in tissue treated with acid ferrocyanide solution (Fig. 1a). The number and size of these granules within the endocardial layer increased rapidly with the time elapsed between the ferritin injection and sacrifice. Thus, these cells were almost completely filled with ferritin $28 \mathrm{~h}$ after the injection, i.e. the Prussian blue precipitations may display a diameter up to $10 \mu \mathrm{m}$ in this tissue (Fig. 1a to d). 

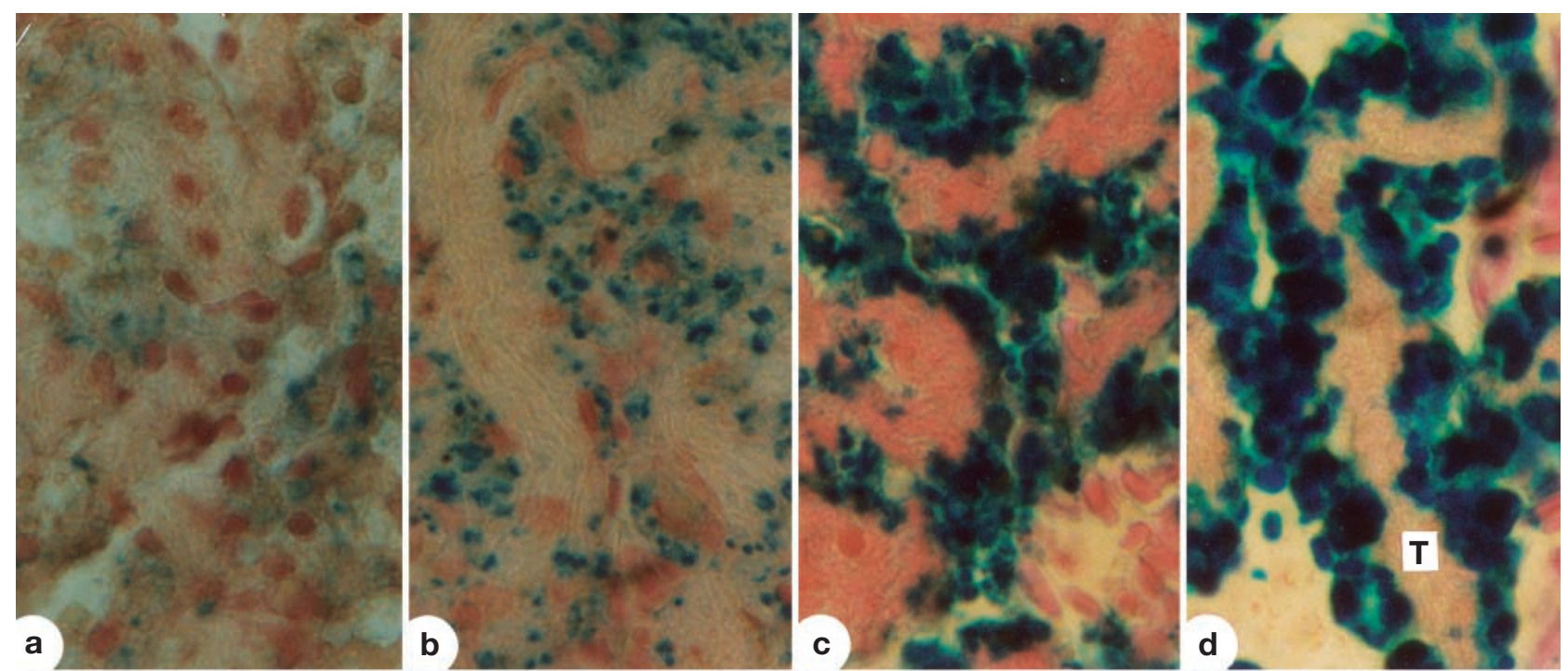

\section{a}

\section{b}
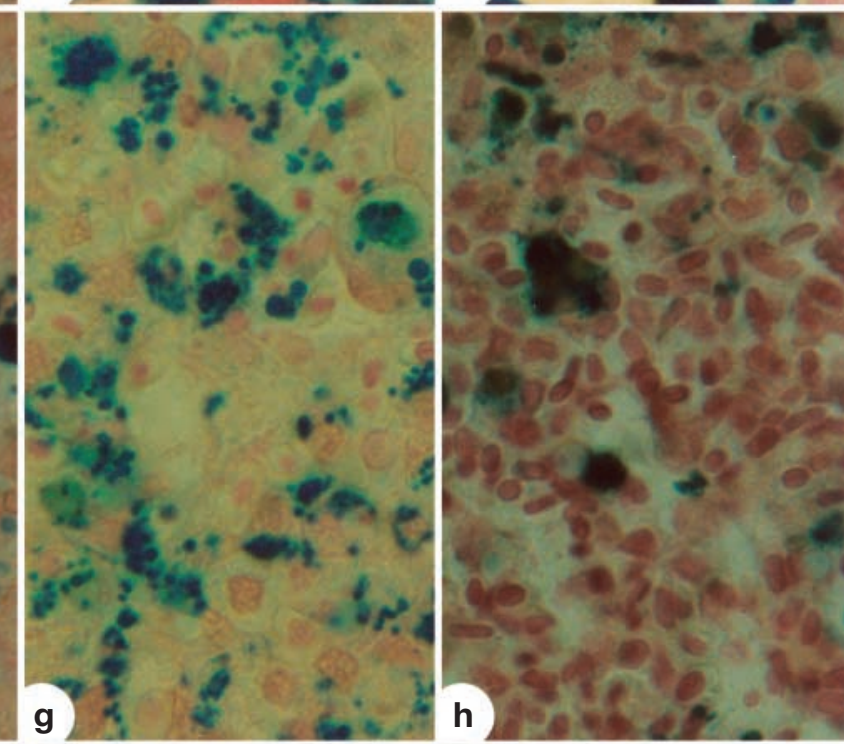

e

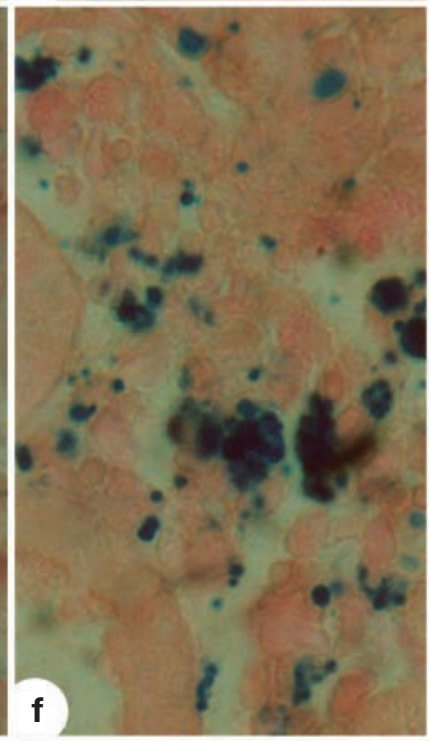

g

$\mathrm{h}$

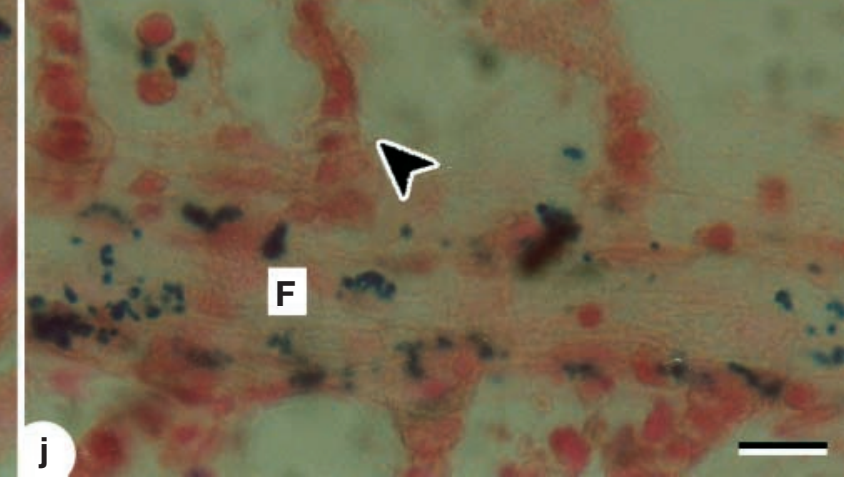

i

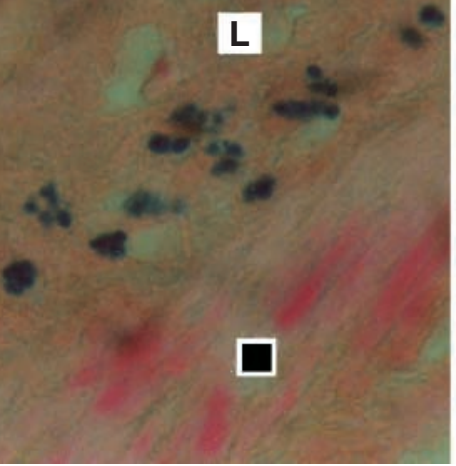

Fig. 1. Xiphophorus maculatus. Various tissues from platy specimens injected intraperitoneally with horse-spleen ferritin. The tissues are treated with acid ferrocyanide solution, i.e. Prussian blue is precipitated in the ferritin-containing cells. Atrial trabeculae (T) (a) $1 / 4$, (b) $1 / 2$, (c) 1.5 and (d) $6 \mathrm{~h}$ after the ferritin-injection; the amount of precipitated Prussian blue within the endocardial layer increases very rapidly with the time elapsed between the injection and the sacrifice. Trunk kidney (e) ${ }^{1 / 4}$ and (f) $6 \mathrm{~h}$ and spleen (h) $1 / 4 \mathrm{~h}$ and $(\mathrm{g}) 26 \mathrm{~h}$ after the ferritin injection; the uptake in these tissues is much less than in the cardiac tissue. The trunk kidney and spleen macrophages are filled by Prussian blue material, i.e. they contain 1 large granule or numerous small, tightly packed granules. The Prussian blue precipitations in the sinusoidal endothelium of the trunk kidney and spleen are arranged into short rows $(\mathrm{g})$ and are few in number. Prussian blue precipitations within macrophages in the intestine (i) and gill (j) $5 \mathrm{~h}$ after the ferritin injection. The intestinal macrophages are mainly located within the lamina propria (L) above the smooth muscle layers (filled square). The gill macrophages are located within the gill filament (F), whereas the gill lamellae (arrowhead) lack such cells. All tissues are stained with neutral red solution. The tissues in (c) and (d) are also stained with eosin solution. Scale bar $=20 \mu \mathrm{m}$ 
Occasionally, ferritin-containing granules also appeared within macrophages in the trunk kidney and spleen $1 / 4 \mathrm{~h}$ after the injection (Fig. 1e,h). Such granules were not seen in the skin, but occurred regularly within the macrophages in the gill and intestine when the time elapsed between the ferritin-injection and sacrifice exceeded 1 and 5 h, respectively (Fig. 1i,j). The number and size of these granules within these tissues also increased rapidly with the time elapsed between the ferritin injection and the sacrifice (Fig. 1e-h). Thus, when this time exceeded $6 \mathrm{~h}$, the macrophages in the trunk kidney, spleen, gill and intestine displayed large Prussian blue precipitations, reaching a diameter up to $10 \mu \mathrm{m} 28 \mathrm{~h}$ after the injection (Fig. 1f,g). Similar precipitations, with a diameter up to $3 \mu \mathrm{m} 28 \mathrm{~h}$ after the injection, were sporadically seen within the sinusoidal endothelial layer of the trunk kidney and spleen (Fig. 1g).
The volume of Prussian blue precipitations per volume unit of the tissue was much larger in the heart than in the other organs studied in the present work (Fig. 1d,f,g).

Eosinophilic and neutrophilic granulocytes were regularly observed in tissues stained with eosin after the ferrocyanide treatment (Fig. 2a,b). Prussian blue precipitations were not seen in these cells.

Tissues from control platy specimens: Cells containing Prussian blue granules were not seen in these tissues (Fig. 2c-g). Eosinophilic and neutrophilic granulocytes were regularly observed in tissues treated with eosin after the ferrocyanide treatment (Fig. 2d).

Discussion. The heart endocardial layer covering the cardiac muscle trabeculae is 'specialized' in some bony fish families, and 'unspecialized' in others (Leknes 1980, 1983). Recent studies have revealed that the specialized endocardium in teleosts is able to take up
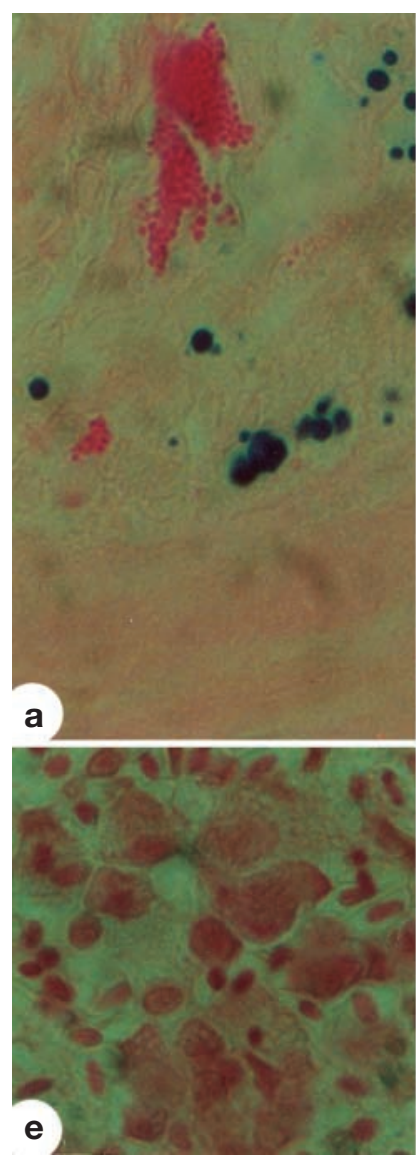
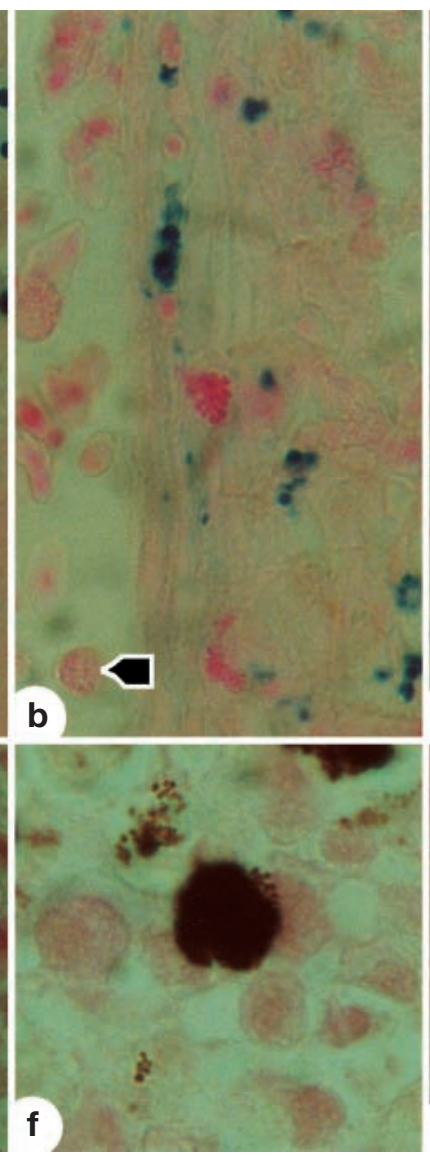
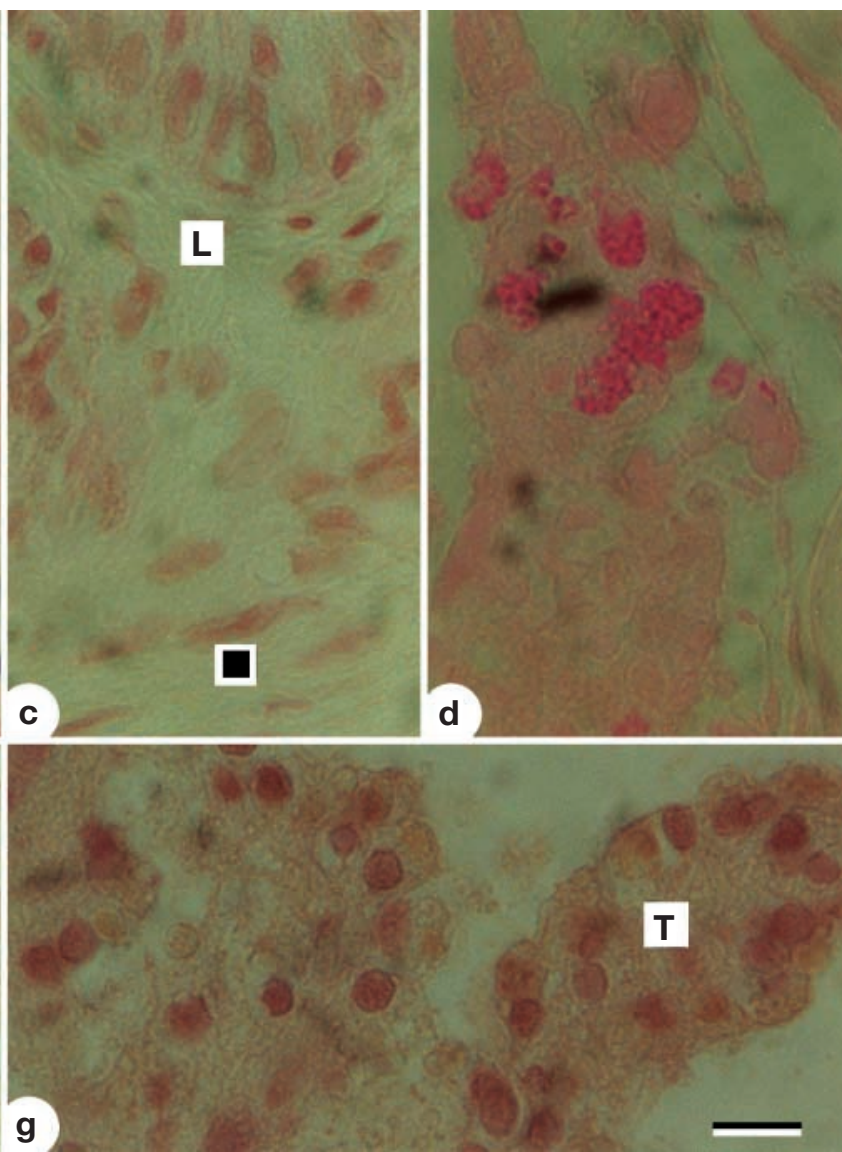

Fig. 2. Xiphophorus maculatus. (a) Intestine and (b) gill from platy, 26 and $11 \mathrm{~h}$ after the ferritin-injection, respectively. The Prussian blue precipitations within the macrophages indicate a ferritin uptake by these cells, whereas the neutrophilic granulocytes (arrow) and the eosinophilic granulocytes cells (packed by red granules) contain no such precipitations. There are no Prussian blue precipitations in the (c) intestine, (d) gill, (e) spleen, (f) trunk kidney and (g) cardiac atrium in the control tissues. The endocardial nuclei appear as circular structures in the periphery of the trabeculum (T) in the atrial tissue in (g). The black cells in (f) are pigment cells, whereas the granulated cells in (d) are eosinophilic granulocytes. All tissues are stained with neutral red solution. The tissues in (a), (b) and (d) are also stained with eosin solution. Scale bar $=20 \mu \mathrm{m}$ 
large amounts of various foreign organic macromolecules from the blood stream (Leknes 1987, Smedsrød et al. 1995, Dalmo et al. 1996, 1997, Sørensen et al. 1998, Leknes 2001a). The macrophages in the trunk kidney and spleen of platy Xiphophorus maculatus are able to internalize foreign proteins (Leknes 2001b).

Macromolecules from the connective tissue metabolism are mainly taken up by the sinusoidal endothelial cells in the rat liver and Atlantic salmon Salmon salar L. kidney (Smedsrød et al. 1990, 1993). In the Atlantic cod Gadus morhua L., however, such macromolecules are mainly taken up from the circulation by the heart endocardium (Smedsrød et al. 1995, Sørensen et al. 1997, 1998). The present study on various tissues from specimens of platy, injected intraperitoneally with horse spleen ferritin, shows a very large uptake of this type of ferritin in the heart endocardial layer, i.e. the volume of the internalized horse-spleen ferritin, per volume unit of the tissue, is far larger in the heart than in the other organs studied in this work. Probably, the endocardial cells in platy play an important role in the uptake and elimination of various metabolic waste substances from the circulation, but, as shown in the present study, they are also able to take up large amounts of foreign proteins. The large ferritin uptake by the platy endocardium revealed in the present study strongly indicates that this tissue has the capacity to take up and eliminate many more waste substances and matters than those normally produced by metabolism. We therefore suggest that the welldeveloped endocytotic ability in this tissue in platy may play a significant role in the defense against various harmful foreign molecules and matters similar in size to the ferritin molecules, including various types of viruses. If so, these cells may have significant immunological functions in this species, as also recently indicated by Smedsrød et al. (1995) for the corresponding cells in gadoids. However, further studies are needed to reveal the exact implications of the advanced sequestration ability of this tissue in poecilid and gadoid species.

Generally, the macrophages in mammals and teleosts play a much smaller role in the endocytotic uptake of waste connective-tissue molecules than the various specialized vascular endocytotic endothelial layers (Smedsrød et al. 1990, 1995). The present study shows, however, that most of the horse spleen ferritin taken up by the platy kidney and spleen is internalized by the macrophages in these organs, i.e. these cells may to some extent be involved in the sequestration and elimination of foreign macromolecules in this species.

The present study shows an uptake of foreign ferritin in the macrophages of the platy gill and intestine similar to that in the kidney and spleen, except that this substance is taken up more slowly in the former 2 organs than in the latter 2. The main functions of the gill and intestinal macrophages are probably to entrap and destroy foreign macromolecules and substances which have passed through the epithelial layer from the surrounding water or the intestinal liquid, respectively (Rombout et al. 1993, Dalmo et al. 1997, Lin et al. 1998, Press \& Evensen 1999). The present results indicate, however, that such cells may also to some extent participate in the clearance of the blood circulation. Such an uptake of ferritin and blood clearance function have, as far as we know, not previously been demonstrated for macrophages in the bony fish gills and intestine. Furthermore, the present study reveals a method, i.e. ferritin injection combined with the ferrocyanide technique, which make it possible to observe such cells in the fish gill and intestine at the light microscopic level. This method may, in particular, be useful to demonstrate the activity and aggregation of such cells in the fish gills and intestine infected with parasitic organisms.

The intestinal eosinophilic granulocytes are able to internalize foreign proteins in the trout intestine (Dorin et al. 1993). The present study shows, however, that the corresponding cells in platy gill and gut are not able to take up horse spleen ferritin. We therefore suggest that these cells in platy are not able to endocytose foreign proteins, but may be purely secrectory as they normally are tightly packed by granules. This assumption is in accordance with the recent proposals that these cells in the bony-fish gill and gut may have functions similar to those of the mammalian mast cells, at least in some teleostean species (Reite 1998).

\section{LITERATURE CITED}

Dalmo RA, Ingebrigtsen K, Sveinbjørnsson B, Seljelid R (1996) Accumulation of immunomodulatory laminaran $(\beta(1,3)$-Dglucan) in the heart, spleen and kidney of Atlantic cod, Gadus morhua L. J Fish Dis 19:129-136

Dalmo RA, Ingebrigtsen K, Bøgwald J (1997) Non-specific defence mechanisms in fish, with particular reference to the reticuloendothelial system (RES). J Fish Dis 20:241-273

Dorin D, Martin P, Sire MF, Smal J, Vernier JM (1993) Protein-uptake by intestinal macrophages and eosinophilic granulocytes in trout-an in-vivo study. Biol Cell 79:37-44

Grimstone AV, Skaer RJ (1972) A guidebook to microscopical methods. Cambridge University Press, London

Leknes IL (1980) Ultrastructure of atrial endocardium and myocardium in three species of Gadidae (Teleostei). Cell Tissue Res 210:1-10

Leknes IL (1983) Ultrastructural and ultrahistochemical studies on ventricular endocardial cells in teleosts (Pisces). J Zool 201:507-513

Leknes IL (1987) Endocytosis of horse-spleen ferritin by bony fish endocardium. Acta Histochem 81:175-182

Leknes IL (2001a) Endocytosis of ferritin and hemoglobin by the trabecular endocardium in swordtail, Xiphophorus helleri L. and platy, Xiphophorus maculatus L. (Poeciliidae: Teleostei). Ann Anat 183:251-254 
Leknes IL (2001b) The uptake of foreign ferritin by macrophages in the spleen, trunk kidney and liver of platy. J Fish Biol 59:1412-1415

Lin SH, Davidson GA, Secombes CJ, Ellis AE (1998). A morphological study of cells isoltated from the perfused gill of dab and Atlantic salmon. J Fish Biol 53:560-568

Pearse AGE (1980) Histochemistry: theoretical and applied. Churchill Livingstone, Edinburgh

Press CMcL Evensen $\varnothing$ (1999) The morphology of the immune system in teleost fish. Fish Shellfish Immunol 9: 309-318

Reite OB (1998) Mast cells eosinophilic granule cells of teleostean fish: a review focusing on staining properties and functional responses. Fish Shellfish Immunol 8:489-513

Rombout JHWM, Tavernethiele AJ, Villena MI (1993) The gut-associated lymphoid tissue (GALT) of carp (Cyprinus carpio L.) - an immunocytochemical analysis. Dev Comp Immunol 17:55-66

Editorial responsibility: Jo-Ann Leong,

Corvallis, Oregon, USA
Smedsrød B, Melkko J, Risteli L, Risteli J (1990) Circulation C-terminal propeptide of type I procollagen cleared mainly via the mannose receptor in liver endothelial cells. Biochem J 271:345-350

Smedsrød B, Gjøen T, Sveinbjørnsson B, Berg T (1993) Catabolism of circulating collagen in the Atlantic salmon (Salmo salar). J Fish Biol 42:279-291

Smedsrød B, Olsen R, Sveinbjørnsson B (1995) Circulating collagen is catabolized by endocytosis mainly by endothelial cells of endocardium in cod (Gadus morhua). Cell Tissue Res 280:39-48

Sørensen KK, Dahl LB, Smedsrød B (1997) Role of endocardial endothelial cells in the turnover of hyaluronan in Atlantic cod (Gadus morhua). Cell Tissue Res 290:101-109

Sørensen KK, Melkko J, Smedsrød B (1998) Scavengerreceptor-mediated endocytosis in endocardial endothelial cells of Atlantic cod Gadus morhua. J Exp Biol 201: $1707-1718$

Submitted: November 27, 2001; Accepted: May 24, 2002

Proofs received from author(s): August 19, 2002 